\title{
The impaired anesthesiologist: what you should know about substance abuse
}

\author{
Stefan T. Samuelson, MD • Ethan O. Bryson, MD
}

Received: 12 July 2016/Revised: 21 October 2016/Accepted: 16 November 2016/Published online: 7 December 2016

(c) Canadian Anesthesiologists' Society 2016

\begin{abstract}
Purpose Despite our considerable experience with the problem of addiction in our specialty, most anesthesia care providers don't know how to identify or help an impaired colleague. The purpose of this article to provide sufficient information on substance use disorder (SUD) to aid in its identification amongst colleagues and to assist in its management.
\end{abstract}

Principal findings Depending on the region, $10-15 \%$ of the general population is prone to developing a SUD and will abuse drugs or alcohol at some point in their life. Physicians and other healthcare professionals are not immune to the disease of addiction and are just as prone to developing SUD as laypersons. Even so, the risk of mortality is significantly increased because of access to potent and highly addictive anesthetic agents with a narrow therapeutic index when self-administered. Also, the number of anesthesia residents who are identified as having SUD is currently increasing.

Conclusions Due to the considerable morbidity and mortality associated with the abuse of anesthetic agents as well as the continuous increase in the rate of substance

\footnotetext{
S. T. Samuelson, MD

Department of Pain Medicine, Mount Sinai West, New York, NY, USA

E. O. Bryson, MD ( $($ )

Departments of Anesthesiology and Psychiatry, Icahn School of Medicine at Mount Sinai, New York, NY, USA

e-mail: ethan.bryson@mountsinai.org
}

abuse by anesthesia providers, it is essential for anesthesia care providers to become familiar with the presenting signs and symptoms of substance abuse and impairment.

\section{Objectives of this Continuing Professional Development (CPD) module:}

After reading this module, the reader should be able to:

1) Cite the current prevalence of drug impairment among anesthesia providers.

2) Describe the key signs suggesting that a colleague might be developing a substance abuse problem.

3) Describe the natural progression of the condition.

4) Describe the procedure that should be followed if you suspect your colleague has a substance abuse problem.

Addiction to anesthetic drugs continues to be a major issue in the anesthesia workplace, with as many as $15 \%$ of anesthesia care providers developing a substance abuse problem at some point during their career. ${ }^{1}$ While a significant portion of these individuals become addicted to alcohol, when anesthetic drugs are involved (chiefly intravenous opiates and propofol), death is frequently the initial presentation of the disease. Despite our considerable experience with the problem of addiction in our specialty and its recognition as an occupational hazard, ${ }^{2}$ anesthesia care providers may be ill-equipped to identify and help an impaired colleague.

The Diagnostic and Statistical Manual of Mental Disorders (DSM-V) incorporates substance abuse and substance dependence into a single disorder-i.e., substance use disorder (SUD), quantified on a scale from mild to severe depending on the number of symptoms present (see Appendices 1 and 2). For the purpose of this 
manuscript, the terms addiction, addicted, and chemical dependence are presumed to indicate SUD.

\section{Current prevalence}

The prevalence of a disease is the percentage of a population-in this case anesthesia care providers (ACPs), including residents, physician anesthesiologists, nurse anesthetists, and anesthesia assistants-that is affected with a particular disease (SUD) at a given time. Since ACPs are a subset of the general population, it is reasonable to assume that the rate of SUD among ACPs mirrors that of the general population. Depending on the region, $10-15 \%$ of the general population is prone to develop SUD and will abuse drugs or alcohol at some point in their life. The total number of impaired professionals is similar, only the types of substances abused are different, reflecting access to controlled drugs. Self-report and departmental surveys of ACPs have indicated that, in addition to alcohol (mostly abused by older anesthesiologists), ${ }^{3}$ commonly abused anesthetic agents include not only benzodiazepines, opiates, ${ }^{4,5}$ propofol, ${ }^{6}$ and ketamine $^{7}$ but also inhalational agents. ${ }^{8-10}$ In comparison to healthcare providers from other specialties who are suffering from chemical dependence, ACPs are more likely to abuse drugs than alcohol and to use drugs intravenously. ${ }^{11}$

In 2005, Collins's survey of United States (US) anesthesiology residency programs found that $80 \%$ had some experience with impaired residents. Sadly, 19\% of these programs reported at least one pre-treatment fatality. ${ }^{12}$

\section{Current incidence}

Incidence, defined as the probability of occurrence of a given medical condition (SUD) in a population (ACPs) within a specified period of time, is a somewhat more useful frame of reference than prevalence. Incidence may be expressed as the number of new cases during a given time period, but it is more commonly reported as a proportion or a rate (number of residents) with a denominator (per 1,000 resident-years). In 2013, Warner et al. investigated the frequency with which SUD occurred within anesthesia residency training programs in the US. ${ }^{13}$ The authors found that $0.86 \%$ of US anesthesiology residents showed evidence of SUD during their training, as reported by their training programs. In this retrospective analysis, 44,612 resident files from the years 1975-2009 were examined, and 384 had documented evidence of SUD. This amounts to an overall incidence of 2.16 [95\% confidence interval (CI), 1.95 to 2.39 ] per 1,000 resident-years. Interestingly, in $29 \%$ of these cases there was evidence that SUD was known to program directors but not reported to the American Board of Anesthesiology. ${ }^{13}$

Since these numbers represent only the known cases, i.e., the cases that were identified because the individual was discovered (overdose, witnessed self-injection, referral to a treatment program, or present on internal or external documentation), the actual incidence (per 1,000 years of training or practice) is probably higher. Historical estimates based on short series and anecdotal reports put the number at $1.5 \%$ among residents, certified registered nurse anesthetists, and junior faculty, and slightly lower for faculty members practicing for more than five years. ${ }^{14}$ During the period examined by Warner et al., the initial rate was followed by a drop during 1996-2002; however, a higher incidence has occurred since 2003 and the trend continues to rise.

\section{Risk factors}

In 2015, Warner's group reported an analysis of the risk factors for the development of SUD in anesthesiology residents in the US and outcomes for residents affected by SUD. ${ }^{15}$ In this population, males were much more likely to develop SUD than females (2.16 per 1,000 resident-years vs 0.65 per 1,000 resident-years, respectively). This was also the case for residents who attended a medical school in the US (odds ratio, 2.4; 95\% CI, 1.6 to 3.7). Program size or type (university, military, or community-based) was not associated with an increased risk. Interestingly, in-training examination scores were not different in the clinical base year, but they were significantly lower in cases of SUD by their second year of training, presumably because the residents began to focus more of their attention on obtaining and using drugs.

There have been many hypotheses proposed to explain why some people develop SUD while others do not. Animal and human studies have investigated epigenetic changes ${ }^{16}$ and novelty-seeking behaviour traits as risk factors for addiction ${ }^{17,18}$ as well as a disproportionately strong response to dopamine-releasing drugs, whether preexisting or drug-induced. ${ }^{19,20}$ Numerous studies have reported that self-medication of symptoms associated with comorbid psychiatric disorders is a risk factor for development of SUD, ${ }^{1,14,21-23}$ and this may be more of a risk factor for female healthcare practitioners than for their male counterparts. ${ }^{22}$ In the case of ACPs, proximity to large quantities of highly addictive drugs has been suggested as a risk factor for SUD, because of easy access and psychological desensitization as well as 
repetitive exposure to microscopic quantities of anesthetic drugs in the operating room environment. ${ }^{24}$ A prior history of treatment for SUD is a risk factor for developing a recurrent SUD (i.e., a relapse) as is a family history of substance abuse and having used a "major opioid" as the drug of choice. ${ }^{25}$ Table 1 itemizes the risk factors associated with the development of substance use disorder and relapse.

\section{Outcomes}

The risk of death is substantially increased in ACPs who develop SUD. In Warner's analysis, 28 cases and no controls died during residency $(7.9 \%$ mortality rate; $95 \%$ CI, 3.1 to 20.5), and the investigators reported that all of these deaths were related to SUD. By the end of the 38year study period (1975-2013), 54 cases $(14.1 \%)$ were deceased compared with ten controls $(1.3 \%)$, although it is unclear how many of those deaths were related to SUD. Beyond mortality, there also exists a substantially increased risk for adverse training outcomes, including failure to complete residency (odds ratio, 14.9; 95\% CI, 9.0 to 24.6), failure to become board certified (odds ratio, 10.4; $95 \%$ CI, 7.0 to 15.5 ), and failure to achieve subspecialty certification (odds ratio, 34.6; 95\% CI, 12.0 to 100.0). The authors did not report on the reasons for these outcomes (e.g., residents left training voluntarily $v s$ residents' return was disallowed). Residents with SUD who completed training were more likely to suffer adverse professional actions unrelated to SUD during their career (hazard ratio, 6.8; $95 \%$ CI, 3.8 to 12.2$)$, including loss (6\%) or restriction (39\%) of medical license. They also remained at significant risk for relapse after the initial episode, although this analysis did not examine the risk factors specific to relapse in this population. While at least two studies have examined these outcomes in anesthesiology residents, similar data for practicing anesthesiologists are difficult to obtain, as they are less closely monitored and therefore SUD may go undetected. Most of the existing data are

Table 1 Risk factors associated with the development of substance use disorder and relapse

\footnotetext{
- Male sex (SUD)

- Comorbid psychiatric illness (SUD)

- Family history of substance abuse (SUD)

- Prior history of substance abuse (SUD, Relapse)

- Prior history of treatment (Relapse)

- Use of a "major opioid" such as morphine, fentanyl, hydromorphone (Relapse)

- No longer involved in treatment or monitoring program (Relapse)
}

SUD $=$ substance use disorder qualitative and come from physician health programs at the state level. ${ }^{24,26}$

\section{Identification}

The person suffering from addiction does not often recognize that their drug use represents a significant problem, and as such, treatment is seldom spontaneously sought. This is especially true for healthcare providers who are notoriously poor at recognizing their own ill health, and it can present a major obstacle to recovery, both prior to and during treatment. Surveys of residents in training found that physicians avoid seeking help for a variety of medical issues out of fear of academic consequences, stigma, and becoming the topic of gossip among colleagues, especially when the issues involve problems with drugs or alcohol. $^{27,28}$ The same can be surmised for practicing ACPs who face potential loss of reputation and livelihood if they seek help. ${ }^{29,30}$ Denial is a common component of SUD, and it is not necessarily limited to the addicted person. Colleagues of an affected individual often do not recognize behaviour that, in retrospect, may have been obvious. Due to the nature of the disease, and the resourcefulness and stamina of addicted ACPs, they may appear functional and "normal" for quite some time. As their job is often the source of the drugs to which they have become addicted, they remain extraordinarily attentive and physically present at work until very late in the course of the disease. Even so, evidence of their impaired state is often present, although it may be subtle. Some tell-tale signs that may be seen in SUD are listed in Table 2.

Some of the behavioural changes listed in Table 2 apply to SUD in any form, while others are specific to scenarios involving abuse of anesthetic drugs. It is noteworthy that SUD may present with the same picture as other types of psychopathology. Mood swings, irritability, anger, and

Table 2 Changes in behaviour frequently observed in addicted anesthesia care providers

- Periods of irritability, anger, euphoria, and depression

- Withdrawal from family, friends, and leisure activities

- Mood swings, with periods of depression alternating with periods of euphoria

- Increased episodes of anger, irritability, and hostility

- Spending more time at the hospital, even when off duty

- Volunteering for extra call

- Refusing relief for lunch or coffee breaks

- Requesting frequent bathroom breaks

- Signing out increasing amounts of narcotics or quantities inappropriate for the given case

- Weight loss and pale skin 
depression are evidence not only of major depressive disorder but also of fatigue, burnout, and simple interpersonal conflict. Euphoria and hostility may be present in bipolar disorder or axis II phenomena (e.g., antisocial or borderline personality disorders), and withdrawal from family, friends, and leisure activities may be present in quite a number of both axis I and axis II pathology. However, when many of these symptoms are present at the same time, especially when they are rapidly progressive, SUD must be considered. In fact, dual diagnosis, i.e., SUD in combination with other psychopathology, including those listed above, is very common in this population as healthcare providers are prone to self-medicate. ${ }^{1,22,23,25,31}$

The signs on the list related to drug access are more specific to ACPs abusing anesthetic drugs. The addicted ACP may appear eager and industrious while becoming omnipresent at work. As the disease of addiction progresses, it becomes increasingly important, and difficult, for the impaired individual to obtain enough drugs to match their rapidly escalating tolerance. They find ways to be around their drug of addiction as much as possible to ensure the possibility of diversion. For example, they appear at the hospital when not on shift or volunteer for extra shifts, and they always have a ready excuse for doing so. There may be a sudden increase in the frequency of bathroom breaks from the operating room, or conversely, individuals may not want other practitioners to oversee their cases and may refuse relief for bathroom and lunch breaks. There may be a rapid escalation in the amount of medication wasted, and a practitioner who was never known to be "heavy handed" with narcotics may begin documenting administration of much higher doses of drugs that are not necessarily appropriate for the patients or cases being covered. Physical changes, such as pallor and weight changes, may appear late in the disease, although the addicted individual will go to great lengths to avoid and/or hide the stigmata of intravenous drug use (e.g., "track marks"). Colleagues, family, and friends may overlook these physical and behavioural changes for some time because they do not happen all at once; however, when seen in combination, these signs (especially those having to do with drug access and case oversight) should raise significant concern.

In contrast to alcohol and "street drugs" such as cocaine and marijuana, intravenous drug use is rapidly progressive. Anesthetic drugs are so powerful and addictive when selfadministered without restraint that the median time from first abuse to detection is four months. While alcohol addiction may take years to become evident, fentanyl dependence takes only months to manifest itself, with most individuals either dead or in treatment within a year. ${ }^{14}$ This is in large part due to the development of opiate tolerance, which is thought to occur in three distinct ways: pharmacokinetic (increased metabolic rate or altered distribution of the drug, resulting in less opiate available at the sites of drug action); pharmacodynamic (sustained and/or repeated use of the drug produces tachyphylaxis via adaptive feedback mechanisms); and learned/behavioural (despite increasing levels of drug intoxication, the user develops the ability to function "normally" through practice as well as physiologic adaptation to preserve homeostasis). ${ }^{32}$ Practically speaking, opioid tolerance manifests as a decrease in the duration and intensity of drug-induced euphoria, central nervous system depression and analgesia, as well as a significant increase in the median lethal dose (LD50). ${ }^{33}$ As physiologic and psychological tolerance progresses, actual physical dependence may develop and self-administration of as much as $1,000 \mu \mathrm{g}$ of fentanyl in a single injection may be required just to stave off the symptoms of withdrawal. At the same time, addiction is characterized by cognitive changes, including impaired judgement, ${ }^{34}$ and the addicted ACP often becomes increasingly reckless in obtaining and self-administering the drug. The disease takes a greater physical and emotional toll on the addict, and difficulties may begin with patients, other ACPs, surgeons, and/or hospital administrators. Absences from duty become frequent, especially on Mondays or after a long weekend. Initially, these behaviours may be attributed to another illness or a financial or social crisis, but as the substance use disorder worsens, the addicted ACP becomes more difficult to find, may not answer pages, and work performance begins to deteriorate.

Early in the course of the disease, before performance at work begins to deteriorate, some of the behaviours associated with addiction may make the addict appear to be quite functional, and identification by others can often be problematic. Due to social discomfort in characterizing a colleague as impaired, it can be difficult to accept that problematic behaviour is a result of addiction. Nevertheless, failure to initiate an investigation because of "uncertainty" masked as concern for the individual represents denial. Denial is a normal coping method; for someone who is not afflicted or familiar with the disease, it can be difficult to understand and accept the significant loss of autonomy that comes with addiction. However, denial in this case can have potentially lethal consequences.

There are a number of reasons to explain denial, for example why intelligent healthcare providers are unwilling to acknowledge SUD in themselves or in a colleague. Physicians-especially ACPs-may think that their advanced expertise in pharmacology and physiology will prevent them from losing control of their drug use. They may rationalize their drug use as self-medication for physical pain, work-related stress, or strain on their 
personal relationships due to playing the "doctor's role". ${ }^{29,35}$ Selflessness is seen as an essential component of a life in medicine, and stoicism can lead to isolation and disordered thinking, including denial.

For the colleagues of an addicted individual, denial arises from the deeply ingrained "physicians' code" to which all young physicians are inevitably exposed. In one early study, only $39 \%$ of physicians were familiar with guidelines on when to report an impaired physician, and almost one-quarter of physicians considered it more important to protect the rights of an individual physician than to protect the good of society. ${ }^{36}$ The so-called "bystander effect" may occur as colleagues try to avoid the social discomfort of casting aspersion on a fellow practitioner. Colleagues may assume that someone else will do whatever is necessary to fix the problem-if there is one. Indeed, the tacit understanding that being identified as an impaired physician-especially an addict-is potentially catastrophic to the hard-won career of a physician adds enormous gravity to the act of such a suggestion.

Late in the disease, as the addicted individual becomes inevitably more reckless with their drug use, unexplained physical injuries, such as cuts and bruises, may appear due to "blackouts" and repeated self-injection while impaired. As physical dependence develops, acute withdrawal may present with physical signs such as pale cool clammy skin, constant sniffling, and diaphoresis. Physical withdrawal is an intensely unpleasant experience characterized by sympathetic overdrive, gastrointestinal upset, myalgia, and dysphoria. ${ }^{37}$ Furthermore, despite the common perception that it is nonlethal, multiple deaths have been reported from sequelae, including dehydration, electrolyte disarray, and heart failure. ${ }^{38}$ The opioid addict who is in acute withdrawal feels desperate; the addicted ACP in withdrawal feels an overpowering compulsion to remain close to their drug of choice. What do you do?

\section{Intervention}

Confrontation of the addicted ACP is a delicate affair and requires assistance from experienced professionals. If you suspect a colleague is impaired, do not confront the individual yourself, as these desperate people have been known to commit suicide once they have been discovered. Instead, immediately contact a member of your department's wellness committee, as this person should have the necessary training to know how to proceed. A coordinated intervention needs to take place and should be handled by trained individuals. Make sure the impaired ACP remains supervised and in a safe place, as addicts often stash their drug of choice in a readily accessible locker or vehicle and may behave recklessly when confronted. Whether or not the individual is deliberately attempting self-harm, the ACP has learned to cope with stress through medications easily capable of incapacitating a human being, and the critical level of stress, combined with fear and humiliation, can lead to a lethal overshot in dosing. Conversely, an impaired physician confronted with the ultimatum of undergoing drug testing may choose to sacrifice their entire career by quitting on the spot rather than risk providing proof of having fallen prey to drug or alcohol addiction. This too is a tragedy, as addiction is a disease and impaired physicians can, with proper treatment, be rehabilitated and return to productive and happy lives and careers.

Before initiating an intervention, a complete and detailed treatment plan should be established, including referral to an inpatient facility that specializes in the treatment of healthcare professionals (HCPs). It is essential to have a plan in place for safe transfer from the intervention to this facility, and this frequently involves immediate supervised transport to prevent an opportunity for the individual to elope or change their mind about receiving treatment.

\section{Treatment}

It is essential that HCPs receive treatment in a facility with expertise in dealing with healthcare practitioners with a chemical dependency. As healthcare providers, physicians may view themselves as somehow different from members of the general population, making successful treatment less likely. In a treatment facility geared towards healthcare practitioners, they can be exposed to other colleagues in similar situations. While the authors acknowledge that this is a controversial statement, physicians are accustomed to viewing others as patients and themselves as caregivers, and they may find it exceedingly difficult to drop this deeply ingrained role when surrounded by non-physicians. Furthermore, they may view themselves as "set apart" in non-physician-focused treatment programs, because other patients may treat them differently upon learning of their profession. Whether in a physician-focused or "layman's" treatment program, the highly addictive nature of the anesthetic drugs and the increased risk of death with relapse necessitates that ACPs are sent for extended residential treatment lasting from two months to a year or more. Treatment begins with medically supervised detoxification and includes monitored abstinence, education regarding SUD, initial exposure to self-help groups, and facilitated group and individual psychotherapy. The intensive treatment model allows for staff contact 
extending up to 12 or more hours per day, seven days per week.

\section{Return to work}

Most regulatory bodies will allow ACPs to return to work after treatment for SUD, provided they remain under the supervision of a health and well-being organization. This supervision typically involves a monitoring contract, usually a minimum of five years in length. The contract mandates regular contact with a caseworker, worksite observation, and random urine or hair screening for use of any unprescribed mood-altering substances, including alcohol. $^{39}$ A gradual return to work is suggested as preferable to an immediate return to full clinical responsibilities following treatment for SUD. At least one academic anesthesia program has had success managing ACPs with SUD in this fashion. ${ }^{40}$ Targeted therapy may help recovering physicians re-establish themselves as safe practitioners. Such therapy is designed to help them recognize and manage situational and emotional cues that were in some way associated with their SUD. ${ }^{41-43}$ Behaviour modification may also help physicians learn psychosocial skills to keep themselves healthy in situations that had previously led them to abuse drugs. ${ }^{29,44}$

At the provincial/state level, physician health programs (PHPs) exist in many forms to help the addicted HCP remain in recovery as well as to monitor their compliance using safeguards to ensure they do not pose a danger to patients. $^{45,46}$ Provided the ACP continues in a health and well-being organization, such as a statewide PHP, there is a strong likelihood that they will remain in full recovery. $^{26,47-49}$ In one study, $80 \%$ of physicians who remained enrolled in a monitoring program remained relapse free after five years. Long-term data, though sparse, are less optimistic. More recent data from Warner's group estimate a $43 \%$ risk (95\% CI, 34 to 51) that survivors will experience at least one relapse by 30 years following the initial episode, and this rate has remained stable over the past 40 years. ${ }^{15}$ While relapse does not preclude subsequent re-recovery, it is especially dangerous for ACPs, and in Werner's study, 13\% of individuals who relapsed died as a direct result of substance use. Because of the significant risk of relapse after the initial episode, coupled with the high risk of death when anesthetic drugs are involved, the decision to allow an ACP to return to work after treatment, regardless of the level of training, should be made on a case-by-case basis by an entity with the training and expertise to assess the risk of substance abuse to the practitioner as well as to the public. Even after obtaining endorsement and permission from regulatory bodies to return to the practice of anesthesia, ACPs with a history of SUD may have great difficulty finding employment, as significant stigma exists regarding SUD and practices may be unwilling to hire them.

The odds of any individual successfully avoiding relapse are significantly increased with complete abstinence from all non-prescribed controlled substances, recreational drugs, and alcohol; regular participation in facilitated group psychotherapy with other recovering HCPs, and regular attendance and participation in 12-step fellowships such as Alcoholics Anonymous or Narcotics Anonymous. Willingness to participate in such lifelong "maintenance" therapy is essential since SUD is a chronic disease with risk of relapse, and even individuals who have successfully completed treatment remain at risk. ${ }^{25}$

\section{Prevention}

Substance use disorder is recognized as an occupational hazard within the practice of medicine, especially in the field of anesthesiology. ${ }^{2,50,51}$ Despite considerable success in some programs, ${ }^{52}$ random drug screening of HCPs remains a contentious issue. Such drug screening has been shown to have apositive deterrent effect in every branch of the United States (US) military, the Department of Transportation, Federal Transit Administration, Federal Aviation Administration, and Federal Railroad Administration. In the US, very few non-military programs perform random drug screens. Hospitals will more commonly require pre-employment or for-cause drug screening; however, as the issue of the addicted HCP has more recently become a topic of public discussion, some are actively promoting the idea. Though not approved by the voters, the California Patient Safety Ballot Initiative (2015) proposed random drug tests for all physicians and would have made that requirement law had it passed.

Proposals have been put forward to evaluate suspicious patterns of drug use through use of anesthesia information management systems and automated dispenser transactions as methods for early identification. Red flags identified during audits include high use of opiates, high wastage of controlled substances, and transactions that occur on cancelled cases, after case completion, or in a different location. Since special equipment is needed to verify the content of a syringe filled with clear liquid, all wasted drugs should be returned to the pharmacy for assay with a hand-held refractometer. Any questionable sample should then be sent out for further analysis. This policy should be made clear to all employees. ${ }^{53}$

One strategy for addressing morbidity and mortality associated with SUD is to actually focus more efforts on primary SUD prevention. Although the field of 
anesthesiology is leading the way in expressly educating trainees about the hazards they may face with regard to SUD, teaching a more "cautious attitude" toward drugs and alcohol in general may help young practitioners arm themselves against this danger in their future. ${ }^{12}$ In addition, education and open discussion within the anesthesia community at large could ensure that ACPs suffering from early-stage chemical dependency feel safe and secure to come forward for help. This would go a long way to help prevent a dangerous situation from progressing into a lethal one.

\section{Conclusion}

Due to the continued increase in the rate of substance abuse by anesthesia providers, early detection of afflicted colleagues remains essential. Some have even suggested that addiction is an occupational hazard for HCPs in anesthesiology. Every training program for individuals (residents and nurses) in anesthesia should deal with the issue of substance abuse and incorporate educational videos that directly address the problem among anesthesia personnel. Since it is not currently possible to identify someone prone to addiction before they become addicted, we must learn to recognize the signs and symptoms of addiction if we are to preserve the safety of both our colleagues and their patients.

While some highly motivated individuals have successfully re-entered the clinical practice of anesthesia and avoided relapse, this is not always the case. Successful completion of an inpatient treatment program does not guarantee freedom from future relapse, even several years into recovery.

\section{Clinical case}

You are the attending anesthesiologist on overnight inhouse call at one of the hospitals for which your group provides coverage. It is early evening and still rather busy, and you cannot locate one of the other attendings on your call team. This physician is a recent graduate and you have not had much opportunity to work with him since he joined your practice. Other colleagues have reported that he is a competent anesthesiologist and never complains about having to stay late when the operating rooms are busy. You need him to start an emergency femoral-popliteal bypass booked by one of your vascular surgeons. The patient is in the holding area and the nurses are ready to go, but the anesthesia machine has not been checked and nothing is set up in the operating room. As the surgeon asks, for the third time, if the patient can be brought into the operating room, your colleague arrives at the control desk, pale and diaphoretic. He reports that he did not receive your pages because the battery in his pager is dead.

Instructions for completing the continuing professional development (CPD) module:

1. Read the current article and the three references indicated in bold.

2. Go to: http://www.cas.ca/Members/CPD-Online and select the current module: The impaired anesthesiologist: what you should know about substance abuse.

3. Answer the multiple-choice questions regarding the case scenario.

4. Once you have entered all of your answers, you will have access to experts' explanations for all the possible choices.

5. Participants may claim up to four hours of CPD for a total of 12 credits under Section 3 of the CPD program of the Royal College of Physicians and Surgeons of Canada.

\section{Les troubles de consommation de substances chez l'anesthésiologiste: ce qu'il faut savoir à propos de la toxicomanie}

\section{Résumé}

Objectif Malgré l'expérience considérable de notre spécialité en matière de dépendance, le personnel d'anesthésie, pour la plupart, ne sait pas comment identifier ou aider un collègue sous l'emprise de drogues. L'objectif de cet article est d'offrir suffisamment d'informations concernant les troubles de consommation de substances (TCS) afin de faciliter leur identification entre collègues et d'aider à leur prise en charge.

Constatations principales Selon la région, $10-15 \%$ de la population générale est encline à manifester un TCS et abusera de drogues ou d'alcool au cours de sa vie. Les médecins et autres professionnels de la santé ne sont pas à l'abri de la maladie de la dépendance et sont tout aussi sujets aux TCS que les non-médecins. Cependant, le risque de mortalité est significativement plus élevé dans cette population en raison de l'accès des professionnels de la santé à des agents anesthésiques puissants et qui provoquent une forte dépendance avec un indice thérapeutique étroit en cas d'auto-administration. De plus, 
le nombre de résidents en anesthésie identifiés comme souffrant d'un TCS est actuellement en croissance.

Conclusion En raison de la morbidité et de la mortalité considérables associées à l'abus d'agents anesthésiques ainsi qu'à l'augmentation constante du taux de toxicomanie parmi le personnel d'anesthésie, il est essentiel que ces professionnels se familiarisent avec les signes et les symptômes de présentation de la toxicomanie et de l'intoxication.

\section{Objectifs de ce module de Développement professionnel continu (DPC):}

Après avoir lu ce module, le lecteur devrait être en mesure de:

1) Indiquer la prévalence actuelle d'intoxication médicamenteuse parmi le personnel d'anesthésie.

2) Décrire les signes clés portant à croire qu'un collègue pourrait commencer à souffrir d'un problème de toxicomanie.

3) Décrire la progression naturelle de la maladie.

4) Décrire la procédure à respecter si vous soupçonnez un collègue de souffrir d'un problème de toxicomanie.

La dépendance aux médicaments anesthésiques demeure un problème majeur dans le milieu de l'anesthésie: en effet, jusqu'à $15 \%$ du personnel d'anesthésie présentera un problème de toxicomanie à un moment donné de sa carrière. ${ }^{1}$ Bien qu'une importante proportion de ces personnes souffrent d'un problème de dépendance à l'alcool, lorsque des médicaments anesthésiques sont impliqués (principalement des opiacés intraveineux et du propofol), le décès constitue fréquemment la première présentation de la maladie. Malgré l'expérience considérable de notre spécialité dans le domaine de la dépendance, et la reconnaissance que ce problème est un risque du métier, le personnel d'anesthésie pourrait être mal préparé pour identifier et aider un collègue intoxiqué.

Le Manuel diagnostique et statistique des troubles mentaux (DSM-V) combine la toxicomanie (soit l'abus de substances) et la dépendance à une substance en un seul diagnostic, soit le trouble de consommation de substances (TCS), quantifié sur une échelle allant de léger à grave selon le nombre de symptômes observés (voir les Annexes 1 et 2). Aux fins de ce manuscrit, les termes dépendance, dépendant et dépendance chimique indiqueront ici un TCS.

\section{Prévalence actuelle}

La prévalence d'une maladie représente le pourcentage d'une population - ici le personnel d'anesthésie, c'est-à-dire les résidents, les anesthésiologistes médecins, les infirmières anesthésistes et les assistants en anesthésie affectée par une maladie en particulier (TCS) à un moment donné. Étant donné que le personnel d'anesthésie représente un sous-ensemble de la population, on peut s'attendre à ce que le taux de TCS parmi le personnel d'anesthésie soit un reflet de celui observé dans la population générale. Selon la région, 10-15\% de la population générale est encline à manifester un TCS et abusera de drogues ou d'alcool au cours de sa vie. Le nombre total de professionnels intoxiqués est semblable, mais les types de substances d'abus sont différents, en raison de l'accès de cette population à des médicaments réglementés. Les auto-évaluations et sondages départementaux réalisés auprès du personnel d'anesthésie indiquent que, outre l'alcool (la substance d'abus de choix des anesthésiologistes plus âgés), ${ }^{3}$ les agents anesthésiques fréquemment abusés comprennent non seulement les benzodiazépines, les opiacés, ${ }^{4,5}$ le propofol $^{6}$ et la kétamine, ${ }^{7}$ mais également les agents volatils. ${ }^{8-10}$ Par rapport à d'autres spécialités, le personnel d'anesthésie court un risque plus élevé d'abuser de médicaments que d'alcool, et de consommer des médicaments par voie intraveineuse. $^{11}$

En 2005, le sondage de Collins sur les programmes de résidence en anesthésiologie aux États-Unis a révélé que 80 $\%$ des programmes avaient déjà eu affaire à des résidents sous l'emprise de drogues. Fait déplorable, $19 \%$ de ces programmes rapportaient au moins un décès avant traitement. $^{12}$

\section{Incidence actuelle}

L'incidence, définie comme la probabilité de survenue d'une condition médicale donnée (TCS) dans une population (le personnel d'anesthésie) dans un intervalle de temps spécifié, constitue un cadre de référence plus utile que la prévalence. L'incidence peut être exprimée en tant que le nombre de nouveaux cas durant une période temporelle donnée, mais elle est plus souvent rapportée sous forme de proportion ou taux (nombre de résidents) avec un dénominateur (par 1000 années-résident). En 2013, Warner et coll. ont examiné la fréquence à laquelle survenaient des TCS dans le cadre des programmes de formation de résidence en anesthésie aux États-Unis. ${ }^{13}$ Les auteurs ont observé que $0,86 \%$ des résidents en anesthésiologie américains avaient été victimes de TCS pendant leur formation, selon le chiffre rapporté par leurs programmes de formation. Dans cette analyse rétrospective, 44612 dossiers de résidents allant de 1975 à 2009 ont été examinés, et 384 comportaient des documents attestant d'un TCS. On parle donc d'une 
incidence globale de 2,16 [intervalle de confiance (IC) 95 $\%, 1,95$ à 2,39] par 1000 années-résident. Fait intéressant, dans $29 \%$ de ces cas, il semblerait que les directeurs de programme étaient conscients du TCS mais ne l'ont pas rapporté à l'American Board of Anesthesiology.

Ces chiffres représentent seulement les cas connus, c'est-à-dire, les cas identifiés parce que la personne a été découverte (surdose, auto-injection devant témoin, référence pour consultation pour un programme de traitement, ou présence de documentation interne ou externe); l'incidence réelle toutefois (par 1000 ans de formation ou de pratique) est probablement plus élevée. Les estimations historiques fondées sur de courtes séries de cas et des comptes rendus anecdotiques placent le taux à $1,5 \%$ parmi les résidents, les infirmièr(e)s anesthésistes certifié(e)s et les jeunes médecins ou anesthésiologistes, et légèrement plus bas chez les médecins pratiquant depuis plus de cinq ans. ${ }^{14}$ Pendant la période étudiée par Warner et coll., le taux initial a été suivi d'une baisse durant les années 1996-2002; toutefois, une incidence plus élevée a été observée depuis 2003 et la tendance est actuellement à la hausse.

\section{Facteurs de risque}

En 2015, le groupe de Warner a publié une analyse des facteurs de risque de survenue d'un TCS parmi les résidents en anesthésiologie aux États-Unis et les pronostics des résidents souffrant de TCS. ${ }^{15}$ Dans cette population, les hommes étaient beaucoup plus enclins à souffrir d'un TCS que les femmes (2,16 par 1000 années-résident vs 0,65 par 1000 années-résident, respectivement). Cette tendance était également observable parmi les résidents inscrits à une école de médecine aux États-Unis (rapport de cotes, 2,4; IC $95 \%$, 1,6 à 3,7). Ni la taille, ni le type de programme (universitaire, militaire ou communautaire) n'étaient associés à un risque accru. Fait intéressant, les notes d'examen des résidents n'étaient pas différentes durant la première année de leur formation; toutefois, les notes étaient significativement plus basses en cas de TCS dès la deuxième année de formation, sans doute parce que les résidents commençaient à se concentrer davantage sur l'obtention et la consommation des drogues.

Plusieurs hypothèses ont été proposées pour expliquer pourquoi certaines personnes sont victimes de TCS et d'autres pas. Les études chez l'animal et l'humain ont examiné les changements épigénétiques ${ }^{16}$ et les traits comportementaux qui poussent à la recherche de nouveauté en tant que facteurs de risque de dépendance, ${ }^{17,18}$ ainsi que les réponses disproportionnées aux médicaments libérant de la dopamine, que ces réponses soient préexistantes ou
Tableau 1 Facteurs de risque associés au développement d'un trouble de consommation de substances et à la rechute

- Sexe masculin (TCS)

- Maladie psychiatrique comorbide (TCS)

- Antécédents familiaux de toxicomanie (TCS)

- Antécédents de toxicomanie (TCS, rechute)

- Antécédents de traitement (rechute)

- Consommation d'un « opioïde majeur » tel que morphine, fentanyl, hydromorphone (rechute)

- N'est plus impliqué dans un programme de traitement ou de supervision (rechute)

TCS $=$ trouble de consommation de substances

induites par un médicament. ${ }^{19,20}$ Plusieurs études ont rapporté que l'auto-médication pour le traitement de symptômes associés à des troubles psychiatriques comorbides était un facteur de risque de manifester un TCS, ${ }^{1,14,21-23}$ et ce facteur de risque pourrait jouer un rôle plus important chez les professionnelles de la santé de sexe féminin que chez leurs pendants masculins. ${ }^{22}$ En ce qui a trait au personnel d'anesthésie, la proximité à d'importantes quantités de médicaments à fort potentiel de dépendance a été suggérée comme facteur de risque de TCS, en raison de l'accès facile et de la désensibilisation psychologique, ainsi que de l'exposition répétée à des quantités microscopiques de médicaments anesthésiques dans l'environnement de la salle d'opération. ${ }^{24}$ Des antécédents de traitement pour un TCS constituent un facteur de risque de TCS récurrent (c.-à-d. de rechute), tout comme des antécédents familiaux de toxicomanie ou la consommation d'un 'opioïde majeur' comme drogue de prédilection. ${ }^{25}$ Le Tableau 1 énumère les facteurs de risque associés au trouble de consommation de substances et à la rechute.

\section{Pronostics et conséquences}

Le risque de décès est considérablement accru chez le personnel d'anesthésie souffrant d'un TCS. Dans l'analyse de Warner, 28 cas étudiés, contre aucun cas témoin, sont décédés pendant la résidence (taux de mortalité $7,9 \%$; IC $95 \%, 3,1$ à 20,5), et les chercheurs ont constaté que tous les décès étaient liés à des TCS. À la fin de la période à l'étude de 38 ans (1975-2013), 54 personnes (14,1\%) étaient décédées, comparativement à dix cas témoins $(1,3$ $\%$ ), même si le nombre précis de décès liés à un TCS n'est pas clair. Outre la mortalité, il existe également un risque considérablement accru de conséquences négatives sur la formation, notamment la non-complétion de la résidence (rapport de cotes, 14,9; IC $95 \%, 9,0$ à 24,6), l'échec à la certification de spécialiste (rapport de cotes, 10,4; IC $95 \%$, 
7,0 à 15,5), et l'échec à la certification de sur-spécialisation (rapport de cotes, 34,6; IC $95 \%, 12,0$ à 100,0). Les auteurs n'ont pas expliqué les raisons de ces résultats (par ex., les résidents ont-ils volontairement abandonné leur formation, ou le retour leur a-t-il a été refusé?). Les résidents souffrant d'un TCS ayant terminé leur formation couraient un risque accru d'être victimes de mesures préjudiciables en matière d'emploi non liées à leur TCS pendant leur carrière (rapport de risque, 6,8; IC $95 \%, 3,8$ à 12,2), notamment la perte $(6 \%)$ ou la restriction (39\%) de leur licence médicale. Un risque important de rechute demeurait également présent après le premier épisode de TCS, bien que l'analyse de Warner n'ait pas examiné les facteurs de risque spécifiques à la rechute dans cette population. Bien que deux études au moins aient examiné ces conséquences chez les résidents en anesthésiologie, des données semblables sont difficiles à obtenir concernant les anesthésiologistes en pratique, étant donné qu'ils sont surveillés de façon moins étroite et qu'un TCS pourrait donc ne pas être détecté. La plupart des données existantes sont qualitatives et proviennent de programmes étatiques de santé des médecins. ${ }^{24,26}$

\section{Identification}

La personne qui souffre d'une dépendance n'est bien souvent pas consciente que sa consommation de drogues ou de médicaments constitue un problème de taille; par conséquent, il est rare que le traitement soit recherché de façon spontanée par la personne intoxiquée. Ceci est particulièrement vrai chez les professionnels de la santé, qui reconnaissent souvent très mal leurs propres problèmes de santé; cela peut constituer un obstacle majeur au rétablissement, tant avant que pendant le traitement. Des sondages réalisés auprès de résidents en formation ont révélé que les médecins évitaient de demander de l'aide pour toutes sortes de problèmes médicaux, que ce soit par peur des conséquences académiques, du stigmatisme, ou de faire l'objet de commérages parmi les collègues - et tout particulièrement lorsqu'il s'agit de problèmes liés à l'alcool ou aux drogues. ${ }^{27,28}$ On peut présumer qu'il en est de même parmi le personnel d'anesthésie en pratique, qui fait face à une perte potentielle de réputation et de gagne-pain s'il demande de l'aide. ${ }^{29,30}$ Le déni est une composante fréquente des TCS, et ne se limite pas nécessairement à la personne qui en souffre. Bien souvent, les collègues d'une personne touchée ne reconnaissent pas des comportements suspects qui, rétrospectivement, deviennent évidents. En raison de la nature de cette maladie, ainsi que de la débrouillardise et de l'énergie du personnel d'anesthésie dépendant, ces personnes pourraient sembler fonctionnelles et 'normales' pendant un certain temps. Étant donné que leur métier est souvent la source des médicaments auxquels elles sont devenues dépendantes, elles sont extraordinairement attentives et présentes physiquement au travail et ce, jusqu'à très tard dans le décours de la maladie. Toutefois, même dans ces conditions, des preuves de leur état intoxiqué sont souvent présentes, bien que possiblement subtiles. Certains des signes révélateurs observés en cas de TCS sont énumérés dans le Tableau 2.

Certains des changements de comportement énumérés au Tableau 2 s'appliquent à n'importe quelle forme de TCS, alors que d'autres sont spécifiques aux cas impliquant un abus de médicaments anesthésiques. Il faut souligner qu'un TCS peut se présenter de la même façon que d'autres types de psychopathologies. Sautes d'humeur, irritabilité, colère et dépression sont des signes non seulement de trouble dépressif majeur, mais également de fatigue, d'épuisement professionnel ou de simple conflit interpersonnel. L'euphorie et l'hostilité peuvent se manifester en cas de trouble bipolaire ou de phénomènes de l'axe 2 (par ex., des troubles de personnalité limite ou antisociale), et le retrait de la famille, des amis et des loisirs peut s'observer avec plusieurs pathologies appartenant tant à l'axe 1 qu'à l'axe 2 . Toutefois, lorsque plusieurs de ces symptômes apparaissent simultanément, particulièrement s'ils évoluent rapidement, il faut envisager la possibilité d'un TCS. En fait, un diagnostic double, c'est-à-dire d'un TCS combiné à une autre psychopathologie, y compris celles énumérées ci-dessus, est très fréquent dans cette population étant donné que les professionnels de la santé ont tendance à s'auto-médicamenter., 1,22,23,25,31

Les signes liés à l'accès aux médicaments, énumérés sur la liste de l'Annexe 2, sont plus spécifiques au personnel d'anesthésie consommant des médicaments anesthésiques de façon abusive. La personne victime de dépendance pourrait apparaître zélée et travailleuse tout en devenant

Tableau 2 Changements de comportement fréquemment observés chez le personnel d'anesthésie dépendant

- Périodes d'irritabilité, de colère, d'euphorie et de dépression

- Retrait de la famille, des amis et des loisirs

- Sautes d'humeur, périodes de dépression alternant avec des périodes d'euphorie

- Augmentation des épisodes de colère, d'irritabilité et d'hostilité

- Augmentation du temps passé à l'hôpital, même lorsqu'il ne travaille pas

- Se porte volontaire pour des gardes supplémentaires

- Refuse d'être remplacé pour le dîner ou les pauses café

- Demande des pauses salle de bains fréquentes

- Retire de la pharmacie (ou des distributrices automatiques) des quantités croissantes de narcotiques, ou des quantités inadaptées au cas qu'il traite

- Perte de poids et pâleur 
omniprésente au travail. Alors que la dépendance progresse, il devient de plus en plus important, et difficile, pour la personne intoxiquée d'obtenir suffisamment de médicaments pour satisfaire sa tolérance qui augmente rapidement. Ces personnes trouvent des façons d'être près de leur médicament de dépendance autant que possible pour garantir la possibilité d'un moment de diversion. Par exemple, elles viennent à l'hôpital lorsqu'elles ne travaillent pas, ou se portent volontaires pour des quarts de travail supplémentaires, et elles ont toujours une excuse toute prête pour se justifier. Il pourrait y avoir une augmentation soudaine de la fréquence des pauses salle de bains de la salle d'opération, ou au contraire, ces personnes pourraient refuser que d'autres praticiens supervisent leurs cas et refusent alors d'être remplacées pour aller aux toilettes ou pour le dîner. On pourrait observer une augmentation rapide de la quantité de médicaments gaspillés, et un praticien qui n'était pas connu comme 'ayant la main lourde' en matière de narcotiques pourrait commencer à documenter l'administration de doses beaucoup plus élevées de médicaments, doses qui ne sont pas forcément adaptées pour les patients ou les cas qu'il couvre. Des changements physiques, tels qu'une pâleur et un changement de poids, peuvent apparaître tardivement dans le décours de la maladie, bien que la personne dépendante déploiera beaucoup d'efforts pour éviter et/ou cacher les traces d'une consommation intraveineuse de médicaments (par ex., des marques sur les bras ou ailleurs). Les collègues, la famille et les amis pourraient ne pas voir ces changements physiques et comportementaux pendant un certain temps, parce qu'ils n'apparaissent pas tous simultanément; toutefois, lorsque vus ensemble, ces signes (particulièrement ceux qui touchent à l'accès aux médicaments et à la supervision des cas) devraient soulever des inquiétudes certaines.

À l'opposé de l'alcool et des 'drogues de rue' telles la cocaïne et la marijuana, la consommation de médicaments par voie intraveineuse progresse très rapidement. Les médicaments anesthésiques sont si puissants et créent une dépendance si intense lorsqu'ils sont administrés sans retenue que le temps moyen entre le premier abus et la détection est de quatre mois. Alors que des années peuvent s'écouler avant qu'une dépendance à l'alcool ne devienne évidente, la dépendance au fentanyl ne prend que quelques mois à se manifester, et la plupart des personnes affectées en meurent ou se retrouvent en traitement dès la première année. ${ }^{14}$ Ceci est en grande partie dû à la tolérance aux opiacés, qui survient de trois façons distinctes: la pharmacocinétique (augmentation du taux métabolique ou distribution altérée du médicament, résultant en une quantité moindre d'opiacé disponible aux sites d'action du médicament); la pharmacodynamique (l'utilisation continue et/ou répétée du médicament provoque une tachyphylaxie via des mécanismes de rétroaction adaptatifs); et de façon apprise/comportementale (malgré des niveaux accrus d'intoxication médicamenteuse, le consommateur devient capable de fonctionner 'normalement' grâce à la pratique ainsi qu'à une adaptation physiologique qui permet de préserver l'homéostasie). ${ }^{32}$ D'un point de vue pratique, la tolérance aux opioïdes se manifeste par une réduction de la durée et de l'intensité de l'euphorie induite par le médicament, une dépression et une analgésie du système nerveux central, ainsi que par une augmentation significative de la dose létale médiane (DL50). ${ }^{33}$ Alors que la tolérance physiologique et psychologique progresse, une dépendance physique réelle pourrait apparaître et une injection unique allant jusqu'à $1000 \mu \mathrm{g}$ de fentanyl pourrait alors être requise simplement pour prévenir les symptômes de sevrage. Dans un même temps, la dépendance se caractérise par des changements cognitifs, notamment un jugement affaibli, ${ }^{34}$ et l'anesthésiste dépendant devient souvent de plus en plus téméraire pour obtenir sa drogue et se l'auto-administrer. La maladie a un coût physique et émotionnel négatif de plus en plus important sur la personne victime de dépendance, et des difficultés pourraient survenir avec les patients, les collègues, les chirurgiens ou d'autres administrateurs de l'établissement. Les absences professionnelles deviennent plus fréquentes, particulièrement les lundis ou après une longue fin de semaine. Au début, ces comportements peuvent être attribués à une autre maladie ou une crise financière ou sociale, mais au fur et à mesure que le TCS empire, la personne dépendante devient de plus en plus difficile à trouver, pourrait ne plus répondre quand on la fait signaler, et sa performance au travail commence à se détériorer.

Au début de la maladie, avant que la performance au travail ne commence à se dégrader, la personne peut sembler tout à fait fonctionnelle grâce à certains des comportements associés à la dépendance; par conséquent, l'identification par autrui peut s'avérer problématique. En raison du malaise social lié à l'identification d'un collègue comme étant sous l'influence de drogues, il peut être difficile d'accepter qu'un comportement problématique soit le résultat d'une dépendance. Toutefois, si l'on n'entame pas une enquête sous prétexte d'une « incertitude » déguisée en inquiétude pour la personne, on est en déni. Le déni est un mécanisme de défense normal; pour une personne qui n'est pas affectée ou qui ne connaît pas bien la maladie, il peut être difficile de comprendre et d'accepter l'importante perte d'autonomie qui accompagne la dépendance. Toutefois, dans ce cas, le déni peut avoir des conséquences potentiellement fatales.

Plusieurs raisons peuvent expliquer le déni, raisons qui élucideraient pourquoi des professionnels de la santé intelligents refusent de reconnaître un TCS chez eux-mêmes ou chez un collègue. Les médecins - et tout particulièrement le 
personnel d'anesthésie - pourraient penser que leur vaste expertise en pharmacologie et en physiologie les protègera d'une perte de contrôle de leur consommation de drogue. Ils pourraient justifier leur consommation de drogues comme une forme d'automédication pour traiter une douleur physique, un stress professionnel, ou encore des tensions dans leurs relations personnelles en raison de leur devoir de jouer « le rôle du docteur ». ${ }^{29,35}$ L'altruisme est perçu comme une composante essentielle de la vie de médecin, et le stoïcisme peut mener à l'isolation et à une perturbation de la pensée, y compris au déni.

Chez les collègues d'une personne dépendante, le déni naît du « code des médecins », profondément ancré, auquel sont inévitablement exposés tous les jeunes médecins. Dans l'une des premières études sur le sujet, seuls $39 \%$ des médecins connaissaient les directives concernant le moment où il faut signaler un médecin sous l'influence de drogues, et près d'un quart des médecins considéraient qu'il était plus important de protéger les droits d'un médecin individuel que de protéger le bien de la société. ${ }^{36}$ Un effet que l'on a décrit comme l'effet du « témoin passif » (ou 'bystander effect') pourrait survenir alors que certains collègues tentent d'éviter le malaise social associé à la dénonciation d'un collègue médecin, en présumant que quelqu'un d'autre fera le nécessaire pour résoudre le problème - si vraiment problème il y a. En effet, il existe une compréhension tacite que l'identification d'un médecin comme étant sous l'influence de drogues - et tout particulièrement comme étant dépendant - peut être potentiellement catastrophique pour la carrière durement gagnée du médecin. Cette compréhension ajoute un poids énorme à l'acte de rapporter l'état possiblement altéré d'un collègue.

Plus tard dans la maladie, alors que la personne dépendante devient inévitablement plus imprudente avec sa consommation de drogues, des blessures physiques inexpliquées, telles que coupures et hématomes, pourraient apparaître en raison 'de pertes de connaissance' et d'auto-injections répétées alors qu'elle est sous influence. $\mathrm{Au}$ fur et à mesure que la dépendance physique progresse, des signes physiques de manque aigu pourraient se manifester, tels qu'une peau moite, pâle et froide, des reniflements incessants, et une diaphorèse. Le sevrage/manque physique est une expérience extrêmement déplaisante qui se caractérise par une surcharge sympathique, des problèmes gastrointestinaux, une myalgie et une dysphorie. ${ }^{37}$ Qui plus est, malgré la croyance populaire que le sevrage n'est pas fatal, de nombreux décès ont été rapportés en raison de ses séquelles, notamment de déshydratation, de perturbation de l'équilibre électrolytique et d'insuffisance cardiaque. ${ }^{38}$ L'opiomane en sevrage aigu se sent désespéré; l'anesthésiste dépendant en sevrage ressent une compulsion irrépressible à rester proche de sa drogue de prédilection. Que devez-vous alors faire?

\section{Intervention}

La confrontation d'un anesthésiste dépendant est délicate et nécessite l'aide de professionnels expérimentés. Si vous soupçonnez qu'un collègue est sous l'emprise de drogues, ne le confrontez pas vous-même; en effet, ces personnes désespérées pourraient commettre un suicide si leur secret est révélé. Au lieu de cela, il faut communiquer immédiatement avec un membre du comité de santé et bien-être du personnel de votre département: cette personne devrait disposer de la formation nécessaire pour savoir comment procéder. Une intervention coordonnée doit avoir lieu et devrait être gérée par des personnes ayant la formation nécessaire. Assurez-vous que la personne intoxiquée demeure supervisée et dans un endroit sécuritaire, étant donné que les personnes dépendantes cachent souvent leurs drogues de prédilection dans un casier ou un véhicule facilement accessible et pourraient avoir un comportement imprévisible lorsqu'on les confronte. Que la personne tente ou non de se faire intentionnellement du mal, ce professionnel de l'anesthésie a appris à gérer son stress à l'aide de médicaments qui pourraient facilement frapper une personne d'incapacité, et un tel niveau critique de stress, combiné à la peur et à l'humiliation, peuvent entraîner la prise d'une surdose létale. À l'inverse, un médecin intoxiqué confronté à l'ultimatum de devoir subir un test de dépistage pourrait choisir de sacrifier toute sa carrière en quittant l'établissement sur-le-champ plutôt que de risquer de voir la preuve qu'il est devenu la proie d'une dépendance à un médicament ou à l'alcool. Cela est tragique, puisque la dépendance est une maladie et les médecins sous l'emprise de drogues peuvent, s'ils reçoivent un traitement adapté, être désintoxiqués et retrouver une vie et une carrière productives et épanouies.

Avant d'amorcer une intervention, un plan de traitement complet et détaillé devrait être établi, comprenant l'admission à un établissement de séjour hospitalier qui se spécialise dans le traitement des professionnels de la santé. Il est essentiel de s'assurer du transfert sécuritaire à cet établissement, et cela implique bien souvent un transport supervisé immédiat afin de prévenir toute occasion, pour la personne intoxiquée, de s'échapper ou de changer d'avis concernant le traitement.

\section{Traitement}

Il est essentiel que les professionnels de la santé reçoivent un traitement dans un établissement qui se spécialise dans la prise en charge de tels professionnels souffrant d'une dépendance chimique. En tant que fournisseurs de soins de santé, certains médecins se considèrent parfois comme 
étant différents de la population générale, ce qui peut rendre le traitement plus difficile. Dans un établissement de traitement s'adressant spécifiquement aux professionnels de la santé, ils seront en revanche exposés à d'autres collègues confrontés à des situations semblables. Bien que les auteurs reconnaissent qu'il s'agit d'une affirmation controversée, les médecins ont l'habitude de percevoir les autres comme des patients et de se voir comme le personnel soignant, et ils pourraient avoir beaucoup de difficultés à laisser de côté ce rôle, profondément ancré dans leur personnalité, lorsqu'ils sont entourés de non-médecins. En outre, ils pourraient se considérer comme «à part » dans des programmes de traitement non spécialisés, car les autres patients pourraient les traiter différemment une fois leur profession connue. Qu'il s'agisse d'un programme de traitement spécialement destiné aux médecins ou d'un programme ouvert à tous, la nature même des médicaments anesthésiques, qui provoquent une dépendance extrêmement forte, ainsi que le risque accru de décès en cas de rechute, justifient que le personnel d'anesthésie soit envoyé dans un programme en résidence à long terme, allant de deux mois à un an, voire plus. Le traitement débute par une désintoxication supervisée par un médecin et comprend une abstinence surveillée, une formation concernant les TCS, une exposition initiale aux groupes d'entraide, et une psychothérapie dirigée de groupe et individuelle. Ce modèle de traitement intensif permet d'être en contact avec le personnel pendant 12 heures ou plus par jour, sept jours sur sept.

\section{Retour au travail}

La plupart des organismes de réglementation permettent au personnel d'anesthésie de retourner au travail après un traitement pour un TCS, tant que ces personnes demeurent supervisées par un organisme de santé et bien-être. Cela implique en général un contrat de supervision, d'une durée minimale habituelle de cinq ans. Ce contrat stipule un contact régulier avec un assistant social, une observation sur le lieu de travail, et des tests aléatoires de dépistage d'urine et de cheveux pour détecter toute utilisation de substances psychotropes, y compris l'alcool. ${ }^{39}$ Un retour progressif au travail est vraisemblablement préférable à un retour 'complet' aux pleines responsabilités cliniques après un traitement pour un TCS. Au moins un programme universitaire d'anesthésie a réussi à prendre en charge son personnel d'anesthésie atteint de TCS de cette manière. ${ }^{40}$ Un traitement ciblé pourrait aussi aider les médecins en voie de rétablissement à reprendre leur place et être acceptés comme étant 'sécuritaires'. Un tel traitement est conçu de façon à les aider à reconnaître et mieux gérer les signaux situationnels et émotionnels qui étaient, d'une façon ou d'une autre, associés à leur TCS. $^{41-43} \mathrm{La}$ modification comportementale peut également aider les médecins à acquérir des compétences psychosociales leur permettant de rester en bonne santé dans les situations qui, précédemment, les avaient poussés à consommer des drogues. ${ }^{29,44}$

$\mathrm{Au}$ niveau provincial et étatique, plusieurs types de programmes de promotion de la santé des médecins existent pour aider le professionnel de la santé ayant subi un TCS à ne pas rechuter, ainsi que pour surveiller leur observance à l'aide de mesures qui permettent de garantir qu'ils ne posent aucun danger pour les patients. ${ }^{45,46}$ Tant que le professionnel de l'anesthésie poursuit son rétablissement au sein d'un organisme de santé et bien-être, comme par exemple un programme provincial/ étatique de santé des médecins, la probabilité qu'il reste en rémission complète est élevée. ${ }^{26,47-49}$ Dans une étude, $80 \%$ des médecins qui sont demeurés inscrits à un programme de surveillance n'ont pas subi de rechute après cinq ans. Les données à long terme toutefois, bien que rares, sont moins optimistes. Des données plus récentes du groupe de Warner estiment à $43 \%$ (IC $95 \%, 34$ à 51) le risque que des survivants subissent au moins une rechute 30 ans après l'épisode initial, et ce taux est demeuré stable au cours des 40 dernières années. ${ }^{15}$ Bien qu'une rechute n'exclue pas un nouveau rétablissement subséquent, elle est particulièrement dangereuse pour le personnel d'anesthésie, et dans l'étude de Warner, $13 \%$ des personnes ayant fait une rechute sont décédées de conséquences directes de la consommation de substances. En raison du risque considérable de rechute après le premier épisode, ajouté au risque élevé de décès lorsque des médicaments anesthésiques sont impliqués, la décision de permettre à un professionnel de l'anesthésie de retourner au travail après son traitement, indépendamment de son niveau de formation, doit se faire au cas par cas par une entité disposant de la formation et de l'expertise nécessaires, afin d'évaluer les risques pour le praticien ainsi que pour le grand public. Même après avoir reçu l'approbation et la permission des organismes de réglementation pour son retour à la pratique de l'anesthésie, le personnel ayant des antécédents de TCS pourrait rencontrer d'importantes difficultés à trouver un emploi. En effet, il existe un stigmatisme considérable concernant les TCS et des centres hospitaliers pourraient hésiter à engager une personne en ayant souffert.

Les chances de n'importe quelle personne d'éviter la rechute sont considérablement augmentées si l'on respecte les mesures suivantes: abstinence complète de toute substance réglementée non prescrite, de drogues douces et d'alcool; participation régulière à une psychothérapie de groupe dirigée avec d'autres professionnels de la santé en rémission, et présence et participation régulières à des 
programmes de rétablissement en 12 étapes, tels que les Alcooliques Anonymes ou les Narcotiques Anonymes. La volonté de participer à un tel traitement 'd'entretien' à vie est essentielle, car le TCS est une maladie chronique comportant un risque de rechute, et même les personnes qui ont réussi leur traitement demeurent à risque. ${ }^{25}$

\section{Prévention}

Le trouble de consommation de substances est reconnu comme étant un risque du métier au sein de la pratique de la médecine, et particulièrement dans le domaine de l'anesthésiologie. ${ }^{2,50,51}$ Malgré le taux de réussite remarquable de certains programmes, ${ }^{52}$ les tests de dépistage aléatoires des professionnels de la santé demeurent controversés. Aux États-Unis, il a été démontré que de tels tests de dépistage avaient un effet dissuasif dans toutes les branches de l'armée, du Département des transports, de l'Administration fédérale de transit, de l'Administration fédérale de l'aviation, et de l'Administration fédérale ferroviaire. Cependant, très peu de programmes non militaires réalisent des tests de dépistage de drogue aléatoires. Les hôpitaux demanderont souvent un dépistage pré-embauche ou pour motif valable; toutefois, étant donné que le problème des professionnels de la santé dépendants a récemment éclaté sur la place publique, certains font désormais la promotion active de l'idée de tests de dépistage aléatoires. Bien qu'elle n'ait pas été approuvée par les électeurs, l'Initiative californienne pour la sécurité des patients (California Patient Safety Ballot Initiative (2015)) proposait des tests de dépistage de drogue aléatoires pour tous les médecins et, si cette initiative avait été acceptée, cette exigence serait devenue loi.

Plusieurs propositions ont été suggérées pour détecter l'utilisation suspecte de drogues à l'aide des systèmes de gestion informatiques en anesthésie, ainsi que les transactions de distributrices de médicaments automatiques comme méthodes de dépistage précoce. Parmi les 'signaux d'alarme' identifiés au cours d'inspections, citons une utilisation exagérée d'opiacés, un gaspillage important de substances réglementées, et le retrait de médicaments d'une distributrice pour des cas annulés, après la fin des cas, ou dans un emplacement autre que celui où les médicaments sont administrés. En cas de soupçons, étant donné que la vérification du contenu d'une seringue remplie de liquide clair nécessite un équipement spécial, tous les médicaments gaspillés devraient être retournés à la pharmacie pour être testés à l'aide d'un réfractomètre portatif. Tout échantillon douteux devrait ensuite être envoyé pour des analyses approfondies. Cette politique devrait être expliquée clairement à tous les employés. $^{53}$

L'une des stratégies pour traiter le problème de la morbidité et de la mortalité associées aux TCS est de concentrer davantage d'efforts sur la prévention première des TCS. Bien que le domaine de l'anesthésiologie soit le chef de file dans l'éducation de ses stagiaires concernant les risques spécifiques qu'ils pourraient courir quant aux TCS, le fait d'enseigner une « attitude plus prudente » envers les médicaments, les drogues et l'alcool en général pourrait aider les jeunes praticiens à se parer contre ce danger à l'avenir. ${ }^{12}$ En outre, la formation et les discussions ouvertes dans la communauté de l'anesthésie dans son ensemble pourraient garantir que le personnel d'anesthésie commençant à souffrir de dépendance chimique se sente suffisamment en sécurité et bien entouré pour oser demander de l'aide. Cette démarche aiderait beaucoup à empêcher une situation dangereuse de devenir fatale.

\section{Conclusion}

En raison de l'augmentation constante du taux de toxicomanie parmi les anesthésistes, le dépistage précoce des collègues affligés demeure crucial. Certains ont même suggéré que la dépendance constitue un risque du métier pour les professionnels de la santé en anesthésiologie. Tous les programmes de formation s'adressant aux personnes (résidents et personnel infirmier) en anesthésie devraient aborder le problème de la toxicomanie et intégrer des vidéos pédagogiques qui traitent directement du problème au sein du personnel d'anesthésie. Étant donné qu'il n'est actuellement pas possible d'identifier une personne encline à la dépendance avant qu'elle ne devienne dépendante, nous devons apprendre à reconnaître les signes et symptômes de la dépendance, si nous souhaitons que nos collègues et leurs patients soient en sécurité.

Alors que certaines personnes très motivées sont parvenues à reprendre la pratique clinique de l'anesthésie et à éviter la rechute, ce n'est pas toujours le cas. La réussite d'un programme de traitement en institution ne garantit pas qu'il n'y aura plus de rechute à l'avenir, même plusieurs années après le rétablissement.

\section{Cas clinique}

Vous êtes l'anesthésiologiste de garde dans un hôpital. C'est le début de la soirée et c'est encore assez occupé, et vous ne parvenez pas à localiser l'un des autres anesthésiologistes traitants de votre équipe. Ce médecin est un diplômé récent et vous n'avez pas eu beaucoup d'occasions de travailler avec lui depuis qu'il s'est joint à 
votre groupe. Selon d'autres collègues, c'est un anesthésiologiste compétent qui ne se plaint jamais de devoir rester tard lorsque les salles d'opération sont pleines. Vous avez besoin qu'il commence un pontage fémoro-poplité d'urgence pour l'un de vos chirurgiens vasculaires. Le patient est dans la salle d'attente et les infirmières sont prêtes, mais la machine d'anesthésie n'a toujours pas été vérifiée et rien n'est préparé dans la salle d'opération. Alors que le chirurgien demande pour la troisième fois si le patient peut être amené en salle d'opération, votre collègue arrive au poste de contrôle de la salle d'opération pâle et diaphorétique. Il déclare qu'il n'a pas reçu vos appels parce que la pile de sa pagette est morte.

\section{Directives pour compléter le module de développement professionnel continu (DPC):}

1. Lisez cet article et les trois références en gras.

2. Allez à: http://www.cas.ca/Membres/modules-de-DPC et choisissez le module actuel: Les troubles de consommation de substances chez l'anesthésiologiste: ce qu'il faut savoir à propos de la toxicomanie.

3. Répondez aux questions à choix multiples portant sur le cas clinique.

4. Une fois que vous aurez répondu à toutes les questions, vous aurez accès aux explications d'experts pour tous les choix possibles.

5. Les participants peuvent réclamer un maximum de quatre heures de DPC pour un total de 12 crédits sous la Section 3 du programme de DPC du Collège royal des médecins et chirurgiens du Canada.

\section{Conflicts of interest None}

Editorial responsibility This submission was handled by Dr. A. Stéphane Lambert, CPD Editor, Canadian Journal of Anesthesia

Funding sources None

Conflit d'intérêt Aucun

Responsabilité éditoriale Cet article a été traité par Dr A. Stéphane Lambert, rédacteur des DPC, Journal canadien d'anesthésie

Sources de financement Aucune

\section{Appendix 1: Substance use disorder criteria}

Substance use disorder in the Statistical Manual of Mental Disorders (DSM-V) combines the DSM-IV categories of substance abuse and substance dependence into a single disorder measured on a continuum from mild to severe. Each specific substance (other than caffeine, which cannot be diagnosed as a substance use disorder) is addressed as a separate use disorder (e.g., alcohol use disorder, stimulant use disorder, etc.), but nearly all substances are diagnosed based on the same overarching criteria. In this overarching disorder, the criteria have not only been combined, but strengthened. Whereas a diagnosis of substance abuse previously required only one symptom, mild substance use disorder in DSM-5 requires two to three symptoms from a list of 11 .

A minimum of two to three criteria is required for a diagnosis of mild substance use disorder, while four to five criteria are considered moderate, and six to seven are deemed severe (American Psychiatric Association, 2013). Opioid use disorder is specified instead of substance use disorder if opioids are the drug of abuse.

Source: http://www.dsm5.org/documents/substance\% 20use \%20disorder\%20fact\%20sheet.pdf.

\section{Appendix 2: Opioid use disorder criteria}

1. Taking the opioid in larger amounts and for longer than intended

2. Wanting but not being able to cut back or quit

3. Spending a lot of time obtaining the opioid

4. Craving or having a strong desire to use opioids

5. Repeatedly unable to carry out major obligations at work, school, or home due to opioid use

6. Continued use despite persistent or recurring social or interpersonal problems caused or made worse by opioid use

7. Stopping or reducing important social, occupational, or recreational activities due to opioid use

8. Recurrent use of opioids in physically hazardous situations

9. Consistent use of opioids despite acknowledgment of persistent or recurrent physical or psychological difficulties from using opioids

10. Tolerance, as defined by either a need for markedly increased amounts to achieve intoxication or a desired effect or a markedly diminished effect with continued use of the same amount (Does not apply for diminished effect when used appropriately under medical supervision)

11. Withdrawal manifesting as either characteristic syndrome or the substance is used to avoid withdrawal (Does not apply when used appropriately under medical supervision)

Further descriptions of specific subclassifications of substance use disorder can be found at http://www. samhsa.gov/disorders/substance-use. 
Annexe 1: Critères pour les troubles de consommation de substances

Dans le plus récent Manuel diagnostique et statistique des troubles mentaux (DSM-V), le trouble de consommation de substances combine les catégories de toxicomanie du DSM-IV et la dépendance à une substance en un seul trouble mesuré sur un continuum allant de léger à grave. Chaque substance spécifique (autre que la caféine, qui ne peut être diagnostiquée comme trouble de consommation de substances) est abordée en tant que trouble de consommation distinct (par ex. trouble de consommation d'alcool, trouble de consommation de stimulants, etc.), mais presque toutes les substances sont diagnostiquées selon les mêmes critères fondamentaux. Dans ce trouble global, les critères ont non seulement été combinés, mais aussi renforcés. Alors que, précédemment, un diagnostic de toxicomanie ne nécessitait qu'un symptôme, un trouble de consommation de substances léger, dans le DSM-5, requiert deux à trois symptômes tirés d'une liste de 11 symptômes.

Un minimum de deux à trois critères est requis pour poser un diagnostic de trouble de consommation de substances léger, alors que quatre ou cinq critères en font un trouble modéré, et six à sept en font un trouble jugé grave (Association psychiatrique américaine - American Psychiatric Association, 2013). On parle d'un trouble de consommation d'opiö̈des plutôt que d'un trouble de consommation de substances, si les opioïdes sont la substance qui est abusée.

Source: http://www.dsm5.org/documents/substance\% 20use $\% 20$ disorder $\% 20$ fact $\% 20$ sheet.pdf.

\section{Annexe 2: Critères pour le trouble de consommation d'opioïdes}

1. Prise d'opioïdes en quantités plus élevées et pour une durée plus longue que prévues

2. Désir mais incapacité de réduire ou d'arrêter de consommer

3. Important investissement de temps passé pour obtenir des opioïdes

4. Envie irrésistible ou désir très fort de consommer des opioïdes

5. Incapacité répétée à remplir des obligations majeures au travail, à l'école ou à la maison en raison de consommation d'opiö̈des

6. Utilisation continue malgré des problèmes sociaux et interpersonnels persistants ou récurrents provoqués ou aggravés par la consommation d'opiö̈des
7. Cessation ou réduction des activités sociales, professionnelles, ou de loisirs importantes en raison de la consommation d'opioïdes

8. Consommation récurrente d'opioïdes dans des situations physiquement dangereuses

9. Consommation continue d'opiö̈des malgré la prise de conscience des difficultés physiques ou psychologies persistantes ou récurrentes provoquées par la consommation d'opioïdes

10. Tolérance, définie par un besoin de quantités croissantes d'opioïdes pour atteindre l'intoxication ou l'effet désiré, ou un effet visiblement diminué avec la consommation d'une quantité constante d'opioïdes (ne s'applique pas pour l'effet diminué observé lors d'une consommation adéquate sous supervision médicale)

11. Sevrage se manifestant soit sous forme de syndrome caractéristique, ou consommation de la substance pour éviter le sevrage (ne s'applique pas lors d'une consommation adéquate sous supervision médicale)

Des descriptions plus détaillées des sous-classifications spécifiques des troubles de consommation de substances sont disponibles en anglais au http://www.samhsa.gov/ disorders/substance-use.

\section{References}

1. Baldisseri MR. Impaired healthcare professional. Crit Care Med 2007; 35(2 Suppl): S106-16.

2. Berry AJ, Katz JD. Occupational health: substance use, abuse, and addiction. In: Barash PG, Cullen BF, Stoelting RK, Cahalan MK, Stock MC, editors. Clinical Anesthesia. 6th ed. Philadelphia, PA: Lippincott Williams \& Wilkins; 2009. p. 74-7.

3. Kintz $P$, Villain $M$, Dumestre $V$, Cirimele $V$. Evidence of addiction by anesthesiologists as documented by hair analysis. Forensic Sci Int 2005; 153: 81-4.

4. Wright EL, McGuiness T, Moneyham LD, Schumacher JE, Zwerling A, Stullenbarger NE. Opioid abuse among nurse anesthetists and anesthesiologists. AANA J 2012; 80: 120-8.

5. Bell DM, McDonough JP, Ellison JS, Fitzhugh EC. Controlled drug misuse by Certified Registered Nurse Anesthetists. AANA J 1999; 67: 133-40.

6. Wischmeyer PE, Johnson BR, Wilson JE, et al. A survey of propofol abuse in academic anesthesia programs. Anesth Analg 2007; 105: 1066-71.

7. Maier C, Iwunna J, Soukup J, Scherbaum N. Addicted anaesthetists (German). Anaasthesiol Intensivmed Notfallmed Schmerzther 2010; 45: 648-54.

8. Sellers WF. Misuse of anaesthetic gases. Anaesthesia 2016; 71 : 1140-3.

9. Garakani A, Jaffe RJ, Savla D, et al. Neurologic, psychiatric, and other medical manifestations of nitrous oxide abuse: a systematic review of the case literature. Am J Addict 2016; 358-69.

10. Wilson JE, Kiselanova $N$, Stevens $Q$, et al. A survey of inhalational anaesthetic abuse in anaesthesia training programmes. Anaesthesia 2008; 63: 616-20. 
11. Gallegos KV, Browne CH, Veit FW, Talbott GD. Addiction in anesthesiologists: drug access and patterns of substance abuse. QRB Qual Rev Bull 1988; 14: 116-22.

12. Collins GB, McAllister MS, Jensen M, Gooden TA. Chemical dependency treatment outcomes of residents in anesthesiology: results of a survey. Anesth Analg 2005; 101: 1457-62.

13. Warner DO, Berge K, Sun H, Harman A, Hanson A, Schroeder $D R$. Substance use disorder among anesthesiology residents, 1975-2009. JAMA 2013; 310: 2289-96.

14. Bryson EO, Silverstein JH. Addiction and substance abuse in anesthesiology. Anesthesiology 2008; 109: 905-17.

15. Warner DO, Berge K, Sun H, Harman A, Hanson A, Schroeder $D R$. Risk and outcomes of substance use disorder among anesthesiology residents: a matched cohort analysis. Anesthesiology 2015; 123: 929-36.

16. Cecil CA, Walton E, Viding E. Epigenetics of addiction: current knowledge, challenges, and future directions. J Stud Alcohol Drugs 2016; 77: 688-91.

17. Abassi M, Abolghasemi A. Temperament and character dimensions: correlates of impulsivity in morphine addicts. Int $\mathbf{J}$ High Risk Behav Addict 2015; 4: e21142.

18. Rodríguez-Arias $M$, Roger-Sánchez C, Vilanova I, et al. Effects of cannabinoid exposure during adolescence on the conditioned rewarding effects of WIN 55212-2 and cocaine in mice: influence of the novelty-seeking trait. Neural Plast 2016; 2016: 6481862.

19. Boileau I, Payer D, Rusjan PM, et al. Heightened dopaminergic response to amphetamine at the D3 dopamine receptor in methamphetamine users. Neuropsychopharmacology 2016. DOI: $10.1038 / \mathrm{npp} .2016 .108$.

20. Stout KA, Dunn AR, Lohr KM, et al. Selective enhancement of dopamine release in the ventral pallidum of methamphetaminesensitized mice. ACS Chem Neurosci 2016; 7: 1364-73.

21. Childress AR, Ehrman R, McLellan AT, MacRae J, Natale M, $O$ 'Brien $C P$. Can induced moods trigger drug-related responses in opiate abuse patients? J Subst Abuse Treat 1994; 11: 17-23.

22. Karpyak VM, Biernacka JM, Geske JR, et al. Gender-specific effects of comorbid depression and anxiety on the propensity to drink in negative emotional states. Addiction 2016; 111: 1366-75.

23. Palhares-Alves HN, Laranjeira R, Nogueira-Martins LA. A pioneering experience in Brazil: the creation of a support network for alcohol and drug dependent physicians. A preliminary report. Rev Bras Psiquiatr 2007; 29: 258-61.

24. Gold MS, Melker RJ, Dennis DM, et al. Fentanyl abuse and dependence: further evidence for second hand exposure hypothesis. J Addict Dis 2006; 25: 15-21.

25. Domino KB, Hornbein TF, Polissar NL, et al. Risk factors for relapse in health care professionals with substance use disorders. JAMA 2005; 293: 1453-60.

26. Skipper GE, Campbell MD, Dupont RL. Anesthesiologists with substance use disorders: a 5-year outcome study from 16 state physician health programs. Anesth Analg 2009; 109: 891-6.

27. Dunn LB, Green Hammond KA, Roberts LW. Delaying care, avoiding stigma: residents' attitudes toward obtaining personal health care. Acad Med 2009; 84: 242-50.

28. Moutier C, Cornette M, Lehrmann J, et al. When residents need health care: stigma of the patient role. Acad Psychiatry 2016; 33 : 431-41.

29. Keeve JP. Physicians at risk. Some epidemiologic considerations of alcoholism, drug abuse, and suicide. J Occup Med 1984; 26 : 503-8.

30. Rosen A, Wilson A, Randal P, et al. Psychiatrically impaired medical practitioners: better care to reduce harm and life impact, with special reference to impaired psychiatrists. Australas Psychiatry 2009; 17: 11-8.

31. Garcia-Guasch R, Roige J, Padros J. Substance abuse in anaesthetists. Curr Opin Anaesthesiol 2012; 25: 204-9.
32. Collett BJ. Opioid tolerance: the clinical perspective. $\mathrm{Br} \mathrm{J}$ Anaesth 1998; 81: 58-68.

33. Jaffe JH. Drug addiction and drug abuse. In: Gilman AG, Goodman LS, Rall TW, Murad F, editors. The Pharmalogical Basis of Therapeutics. 7th ed. New York: Macmillan; 1985. p. 532-81.

34. Rezapour T, DeVito EE, Sofuoglu M, Ekhtiari H. Perspectives on neurocognitive rehabilitation as an adjunct treatment for addictive disorders: from cognitive improvement to relapse prevention. Prog Brain Res 2016; 224: 345-69.

35. Carinci AJ, Christo PJ. Physician impairment: is recovery feasible? Pain Physician 2009; 12: 487-91.

36. Farber NJ, Gilibert SG, Aboff BM, Collier VU, Weiner J, Boyer $E G$. Physicians' willingness to report impaired colleagues. Soc Sci Med 2005; 61: 1772-5.

37. American Psychiatric Association. Diagnostic and Statistical Manual of Mental Disorders I, 5th ed. Washington, DC; 2013.

38. Darke $S$, Larney $S$, Farrell $M$. Yes, people can die from opiate withdrawal. Addiction 2016. DOI:10.1111/add.13512.

39. Shore JH. The Oregon experience with impaired physicians on probation. An eight-year follow-up. JAMA 1987; 257: 2931-4.

40. Bryson EO, Levine A. One approach to the return to residency for anesthesia residents recovering from opioid addiction. J Clin Anesth 2008; 20: 397-400.

41. Conklin CA, Tiffany ST. Applying extinction research and theory to cue-exposure addiction treatments. Addiction 2002; 97: 15567.

42. Heinze M, Wolfling K, Grusser SM. Cue-induced auditory evoked potentials in alcoholism. Clin Neurophysiol 2007; 118: 856-62.

43. Marissen MA, Franken IH, Blanken P, van den Brink $W$, Hendriks VM. Cue exposure therapy for the treatment of opiate addiction: results of a randomized controlled clinical trial. Psychother Psychosom 2007; 76: 97-105.

44. Wilkerson M. Effective components of treatment for the chemically dependent physician. J Okla State Med Assoc 2006; 99: 547-8.

45. Boyd JW, Knight JR. Ethical and managerial considerations regarding state physician health programs. J Addict Med 2012; 6: 243-6.

46. DuPont RL, McLellan AT, Carr G, Gendel M, Skipper GE. How are addicted physicians treated? A national survey of Physician Health Programs. J Subst Abuse Treat 2009; 37: 1-7.

47. DuPont RL, McLellan AT, White WL, Merlo LJ, Gold MS. Setting the standard for recovery: Physicians' Health Programs. J Subst Abuse Treat 2009; 36: 159-71.

48. Gallegos $K V$, Lubin BH, Bowers C, Blevins JW, Talbott GD, Wilson $P O$. Relapse and recovery: five to ten year follow-up study of chemically dependent physicians-the Georgia experience. Md Med J 1992; 41: 315-9.

49. McLellan AT, Skipper GS, Campbell M, DuPont RL. Five year outcomes in a cohort study of physicians treated for substance use disorders in the United States. BMJ 2008; 337: a2038.

50. Aach RD, Girard DE, Humphrey H, et al. Alcohol and other substance abuse and impairment among physicians in residency training. Ann Intern Med 1992; 116: 245-54.

51. Talbott GD, Gallegos KV, Wilson PO, Porter TL, The Medical Association of Georgia's Impaired Physicians Program. Review of the first 1000 physicians: analysis of specialty. JAMA 1987; 257: 2927-30.

52. Fitzsimons $M G$, Baker KH, Lowenstein E, Zapol WM. Random drug testing to reduce the incidence of addiction in anesthesia residents: preliminary results from one program. Anesth Analg 2008; 107: 630-5.

53. Bryson $E O$, Hamza $H$. The drug seeking anesthesia care provider. Int Anesthesiol Clin 2011; 49: 157-71. 